\title{
HYPOTONIA IN KWAZULU NATAL - PREVALENCE AND CAUSeS
}

\begin{abstract}
Benign Congenital Hypotonia (BCH) is a condition whose specific diagnosis and causes are elusive. Time and intensive diagnostic screening allows for unmasking of a specific diagnosis in some cases. The remaining cases are considered to have a good prognosis with resolution by adolescence. For physiotherapy to facilitate development in the intervening period, knowledge of prevalence and causes of the disorder is paramount. Limited information on prevalence of " $\mathrm{BCH}$ " exists in the world and none exists for either KwaZulu Natal or South Africa. This study investigated the prevalence of, and precipitating factors for Hypotonia in

Dawson PMT, B. Physio', Puckree T, Ph.D. PT ${ }^{2}$

${ }^{1}$ Masters student at the University of Durban Westville Physiotherapy Department.

${ }^{1}$ Associate professor at the University of KwaZulu Natal Physiotherapy Department.

KwaZulu Natal. Four hundred children aged 6-7 years, from 16 schools in 8 educational zones participated in the study. The Standardized Motor Test Battery was used to differentiate normal children from those with signs and symptoms of BCH. 101 children tested positive for Hypotonia. Questionnaires to determine potential causes of Hypotonia were administered to these children and an age-matched cohort of 400 normal children. The main predictors of Hypotonia were assisted vaginal delivery and reduced physical activity. We conclude that Hypotonia is a significant, unrecognized disorder amongst our children. Prevention should be the goal of primary health care to reduce the prevalence.
\end{abstract}

\section{KEY WORDS: BENIGN CONGENITAL HYPOTONIA, PREVALENCE, CAUSES, KWAZULU NATAL}

\section{INTRODUCTION}

Hypotonia is often a condition (Benign Congenital Hypotonia) in its own right apart from being a symptom of common pediatric and adult pathological disorders (Parush et al 1998). As a symptom it is recognized and intervention applied to prevent it affecting normal function. As a condition it is poorly understood and not adequately addressed by the clinician or researched to report prevalence, incidence, causes, pathophysiology or evidence based management, especially in South Africa.

$\mathrm{BCH}$ is a condition in which the low tone affects gross and fine motor skills in a developing child (Parush et al 1998). Environmental stimulation and inclusion in a variety of play which pro-

\section{CORRESPONDENCE TO:}

Prof. T. Puckree

Department of Physiotherapy

University of KwaZulu Natal-

Westville Campus

Private Bag X54001

Durban 4000

Tel: 27031260 7977/7817

Fax: 270312608106

E-mail: puckreet@ukzn.ac.za mote the development of gross and fine motor skills are below normal in a hypotonic child (Parush et al 1998). These therefore impair the development of the child as a whole and his/her participation in normal functional and school activities (Parush et al 1998). If diagnosed and addressed by a multidisciplinary team, the prognosis is excellent (Parush et al 1998) with almost full restoration by adolescence. To address the problem of $\mathrm{BCH}$ in our communities, it is important to know its status.

The prevalence of $\mathrm{BCH}$ in Britain (Roussounis et al 1987), United States of America (Shanks-Seller 1995; Missiuna and Pollock 1995) and Australia (Piek and Coleman-Carmen 1995) has been reported. The prevalence of Hypotonia in KwaZulu Natal or South Africa is unknown. In addition, since prevention is so critical, it is important to understand the predisposing factors in order to plan preventative intervention programs at the community level.

The purpose of the present study was to determine the prevalence, and predisposing factors of Hypotonia in KwaZulu Natal. Since BCH is of elusive diagnosis, this study will report on Hypotonia as a condition, and not $\mathrm{BCH}$.

\section{METHODS}

In order to obtain a representative sample, sampling had to be undertaken by randomly selecting schools from rural and urban areas within every educational zone in KwaZulu Natal. Therefore a list of educational zones and the schools within each zone was obtained from the Education Department of KwaZulu Natal. Urban rural differentiation was based on the definition used by Statistics (2002), South Africa (SA). This selection also considered racial and gender representivity within schools. The racial and gender ratios for children in KZN was obtained from Statistics SA (2002) and the ratios used to sample children from the schools. The age group (6 to 7 years) of children was predetermined based on the literature and a sample size of 400 was considered.

In order to identify children with Hypotonia, a suitable motor test which identifies motor deficits and discriminate motor performance at different ages as specifically occurs in "BCH" was chosen. Several factors had to be considered in the choice of the instrument. It had to be easy to use, valid and reliable and not time consuming to administer. The Standardized Motor Test Battery 
Table 1:The 6 subtests and failure criteria for each test, of the STMB.

\begin{tabular}{|c|c|c|}
\hline \multicolumn{3}{|c|}{ Fine motor tests } \\
\hline 1 & Finger Tapping & $\begin{array}{l}N \text { umber of taps performed with index finger in } 10 \text { seconds (right and left) hand and } \\
\text { forearm flat on the table. Individual finger movements are scored. (Failure criteria: } \\
<\mathbf{2 2} \text { taps in } \mathbf{1 0} \text { seconds) }\end{array}$ \\
\hline 2. & Peg Moving & $\begin{array}{l}\text { Record time taken to transfer } 10 \text { plastic } 10 \mathrm{~mm} \text { pegs from on end row of holes in board to } \\
\text { opposite end row of holes ( using left hand, transfer left to right and vice versa). The peg } \\
\text { board was } 275 \mathrm{~mm} \times 275 \mathrm{~mm} \text { with } 10 \text { rows of } 10 \text { holes. This is a standard peg board } \\
\text { found in occupational therapy departments. (Failure Criteria: }>\mathbf{2 1} \text { seconds) }\end{array}$ \\
\hline 3 & Bead Threading & $\begin{array}{l}\text { Record time taken to thread five } 12.5 \mathrm{~mm} \text { diameter beads with } 3 \mathrm{~mm} \text { diameter holes onto a } \\
\text { lace with a } 30 \mathrm{~mm} \text { metal end piece. (Failure criteria: }>\mathbf{2 7} \text { seconds) }\end{array}$ \\
\hline \multicolumn{3}{|c|}{ Gross motor } \\
\hline 4 & Standing on one leg & Up to 30 seconds . right and left (Failure criteria: < 10 seconds) \\
\hline 5 & hopping & $\begin{array}{l}\text { Count number of continuous hops (up to } 30) \text { in a marked } 18 \text { inch }(45 \mathrm{~cm}) \text { square } \\
\text { (right and left). (Failure criteria : }<\mathbf{6} \text { hops) }\end{array}$ \\
\hline 6 & $\begin{array}{l}\text { Walking along a } \\
\text { straight line(tape) }\end{array}$ & $\begin{array}{l}6 \text { feet }(180 \mathrm{~cm}) \text { and } 11 / 2 \text { inches }(33 / 4 \mathrm{~cm}) \text { wide. walking heel toe from one end to the } \\
\text { other without stepping off. Three trials. If the foot becomes completely displaced. If the } \\
\text { tape on } \mathbf{2} \text { out of } \mathbf{3} \text { trials, the test is failed. }\end{array}$ \\
\hline
\end{tabular}

(SMTB) was chosen and piloted on 10 children of the selected age to test reliability and validity. This test was also piloted by Roussounis et al (1987).

To administer the 6 subtests within the SMTB, a stopwatch was also used. Table 1 shows the 6 subtests of the SMTB. A questionnaire was used to capture information on the demographics and test scores of the children. A second questionnaire allowed recording of information about prenatal history, birth history, infant details, physical stimulation and socioeconomic information. Both questionnaires were tested for validity and reliability prior to use. Other equipment used included a bead threading set, peg board set, chalk, tape to mark the 6 foot long line, score sheets.

The study was approved by the Ethics committee of the University of DurbanWestville. Permission to conduct the study was obtained from the Department of Education, KZN. All parents of the children who participated in the study signed fully informed consent forms which were also translated into Zulu for some parents.

The SMTB was administered to every selected child. Thereafter, every child was issued with the 2 questionnaires which were completed by the parents.

Table 2: Number of children tested, Gender and urban and general prevalence proportion and \% in tested children by educational zone.

\begin{tabular}{|l|l|l|l|l|l|}
\hline $\begin{array}{l}\text { Educational } \\
\text { Zone }\end{array}$ & $\begin{array}{l}\text { Number } \\
\text { tested }\end{array}$ & $\begin{array}{l}\text { Total } \\
\text { number } \\
\text { failed } \\
\text { test }\end{array}$ & $\begin{array}{l}\text { Prevalence } \\
\text { proportion } \\
\text { and } \%\end{array}$ & $\begin{array}{l}\% \\
\text { Males } \\
\text { failed }\end{array}$ & $\begin{array}{l}\% \\
\text { Urban } \\
\text { failed }\end{array}$ \\
\hline Empangeni & 50 & 16 & $1: 3.2(32 \%)$ & $9(56,25 \%)$ & $4(25 \%)$ \\
\hline Ladysmith & 50 & 16 & $1: 3.1(32 \%)$ & $9(56,25 \%)$ & $9(56,25)$ \\
\hline North Durban & 50 & 14 & $1: 3.6(28 \%)$ & $12(85,71 \%)$ & $5(35,71 \%)$ \\
\hline Pietermaritzburg & 50 & 7 & $1: 7.1(14 \%)$ & $4(57,14)$ & $3(42,86)$ \\
\hline Port Shepstone & 50 & 7 & $1: 7.1(14 \%)$ & $5(71,43)$ & $0(0 \%)$ \\
\hline South Durban & 50 & 16 & $1: 3.1(32 \%)$ & $8(50 \%$ & $7(43,75 \%)$ \\
\hline Ulundi & 50 & 11 & $1: 4.5(22 \%)$ & $7(63,64 \%)$ & $6(54,54 \%)$ \\
\hline Vryheid & 50 & 14 & $1: 3.6(28 \%)$ & $10(71,42 \%)$ & $9(64,29 \%)$ \\
\hline KZN & 400 & 101 & $1: 4.0(25.3 \%)$ & $64(63,37 \%)$ & $43(42,57 \%)$ \\
\hline
\end{tabular}

\section{DATA ANALYSIS}

The criteria for failure were set at the performance below the 10th percentile regardless of right or left-handed dominance (Roussounis et al 1987). If a child failed 2 tests in either the fine or gross motor areas, $\mathrm{BCH}$ was suspected. The failure criteria are listed in Table 1. Prevalence proportion in the province was calculated. Prevalence proportions based on race, and gender was also determined. The information from the questionnaires were extracted and categorized. Prevalence proportion by gender, racial group and geographical area was calculated. Chi-square tests were used to determine the association between the predictors and $\mathrm{BCH}$ univariately with a probability of 0.05 . The Odds Ratio was also calculated to identify the risk variables. 
Table 3: The racial distribution of children presenting as $\mathrm{BCH}$ in specific regions of KwaZulu Natal.

\begin{tabular}{|c|c|c|c|c|c|}
\hline $\begin{array}{l}\text { Educational } \\
\text { zone }\end{array}$ & African & Asian & Caucasian & Coloured & Total \\
\hline $\begin{array}{l}\text { Empangeni } \\
\text { Total } \\
\text { Failed }\end{array}$ & $\begin{array}{l}47 \\
13\end{array}$ & $\begin{array}{l}3 \\
3\end{array}$ & - & - & $\begin{array}{l}\mathbf{5 0} \\
16\end{array}$ \\
\hline $\begin{array}{l}\text { Ladysmith } \\
\text { Total } \\
\text { Failed }\end{array}$ & $\begin{array}{l}38 \\
12\end{array}$ & $\begin{array}{l}12 \\
4\end{array}$ & - & - & $\begin{array}{l}\mathbf{5 0} \\
16\end{array}$ \\
\hline $\begin{array}{l}\text { N orth Durban } \\
\text { Total } \\
\text { Failed }\end{array}$ & $\begin{array}{l}26 \\
6\end{array}$ & $\begin{array}{l}11 \\
6\end{array}$ & $\begin{array}{l}\mathbf{1 1} \\
1\end{array}$ & $\begin{array}{l}2 \\
1\end{array}$ & $\begin{array}{l}\mathbf{5 0} \\
14\end{array}$ \\
\hline $\begin{array}{l}\text { Pieterma ritburg } \\
\text { Total } \\
\text { Failed }\end{array}$ & $\begin{array}{l}47 \\
6\end{array}$ & - & - & $\begin{array}{l}3 \\
1\end{array}$ & $\begin{array}{l}\mathbf{5 0} \\
7\end{array}$ \\
\hline $\begin{array}{l}\text { Port Shepstone } \\
\text { Total } \\
\text { Failed }\end{array}$ & $\begin{array}{l}48 \\
5\end{array}$ & $\begin{array}{l}2 \\
2\end{array}$ & - & - & $\begin{array}{l}\mathbf{5 0} \\
7\end{array}$ \\
\hline $\begin{array}{l}\text { South Durban } \\
\text { Total } \\
\text { Failed }\end{array}$ & $\begin{array}{l}47 \\
14\end{array}$ & - & $\begin{array}{l}4 \\
2\end{array}$ & - & $\begin{array}{l}\mathbf{5 1} \\
16\end{array}$ \\
\hline $\begin{array}{l}\text { Ulundi } \\
\text { Total } \\
\text { Failed }\end{array}$ & $\begin{array}{l}\mathbf{5 0} \\
11\end{array}$ & - & - & - & $\begin{array}{l}\mathbf{5 0} \\
11\end{array}$ \\
\hline $\begin{array}{l}\text { Vryheid } \\
\text { Total } \\
\text { Failed }\end{array}$ & $\begin{array}{l}47 \\
13\end{array}$ & $\begin{array}{l}2 \\
1\end{array}$ & - & - & $\begin{array}{l}49 \\
14\end{array}$ \\
\hline $\begin{array}{l}\text { KZN } \\
\text { Total } \\
\text { Failed }\end{array}$ & $\begin{array}{l}\mathbf{3 5 0} \\
80 \\
(23 \%)\end{array}$ & $\begin{array}{l}30 \\
16 \\
(53 \%)\end{array}$ & $\begin{array}{l}15 \\
3 \\
(20 \%)\end{array}$ & $\begin{array}{l}\mathbf{5} \\
2 \\
(40 \%)\end{array}$ & $\begin{array}{l}\mathbf{4 0 0} \\
101 \\
(25 \%)\end{array}$ \\
\hline
\end{tabular}

Figure 1: Comparison of Birth History of normal children $(n=280)$ and those testing positive for "BCH" $(n=95)$.

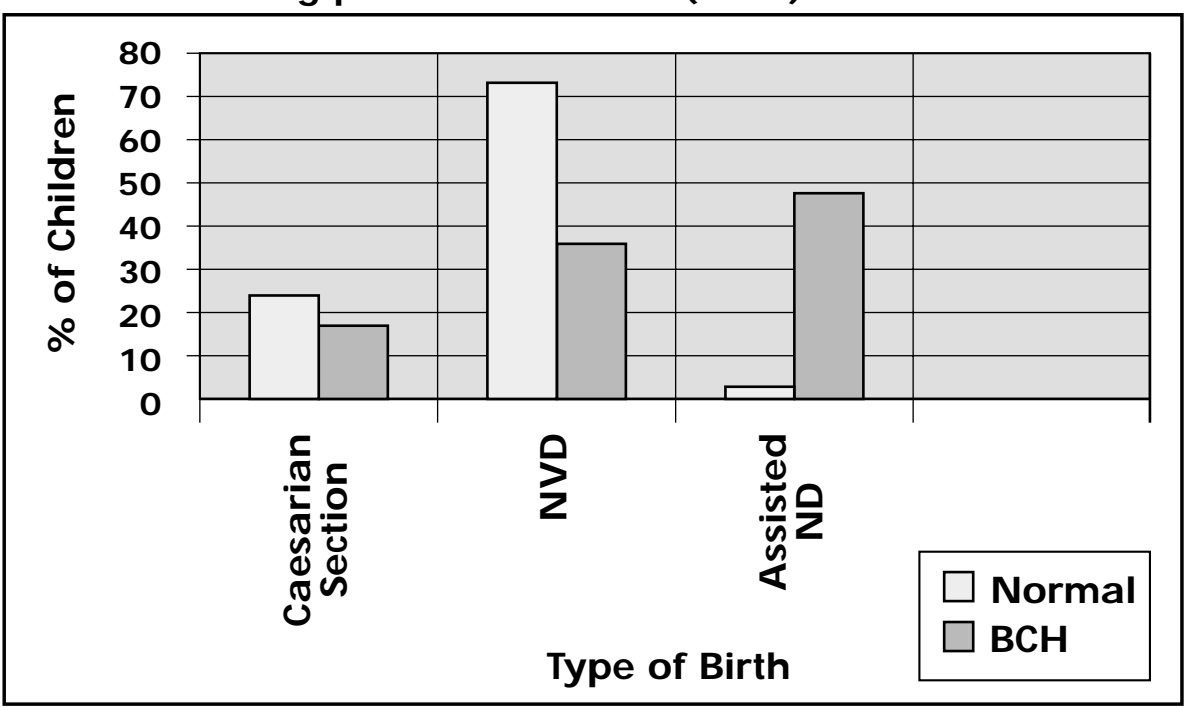

\section{RESULTS}

As shown in Table 2, 400 children who matched the selection criteria from 16 schools in 8 educational zones in kwaZulu Natal were tested. The racial, gender and geographic distribution ratios are also shown.

Table 2 shows the numbers of children tested in each educational zone, the numbers who failed the SMTB and the calculated prevalence proportion. Twenty five percent of the tested children were positive for Hypotonia. The range was between 14 to $32 \%$ with some regions having a higher prevalence than others.

The gender and urban prevalence $\%$ in tested children in each zone is shown in Table 2. The majority of the tested children who failed the tests were male regardless of zone. In addition, the children who identified as being positive for Hypotonia came from rural areas with the exception of zones which normally would be considered rural. Overall almost $58 \%$ of the positively testing children came from rural area.

Table 3 also shows that the majority of the children testing positive for Hypotonia were of Asian descent (53\%) followed by children from the coloured group. Overall $25 \%$ of the children presented with Hypotonia.

For the second part of the study, 93,75 percent of questionnaires were returned. 95 of the 101 questionnaires were returned from the parents of children who were identified as Hypotonia and 280 of 299 questionnaires from normal children. Information extracted from the questionnaires allowed to identify possible predisposers to Hypotonia and compare birth and socioeconomic histories of normal and children presenting with Hypotonia.

As shown in Figure 1, the majority of the children considered to be normal were born by NVD. On the other hand children found to be positive for Hypotonia were born mainly by assisted vaginal delivery.

The predisposing factors that were investigated were level of physical activity, socioeconomic activity, substance abuse during pregnancy and maternal medical condition during pregnancy. A significantly high number $(73,68 \%)$ of children who failed the motor tests 
reported a low level of physical activity. On the other hand a significantly large proportion $(81 \%)$ of the children who passed the motor tests reported a high level of physical activity.

Substance abuse during pregnancy was not significantly different between the 2 groups of children. Significantly more mothers in the test group presented with medical conditions during pregnancy compared to the control one. Socioeconomic status was not significantly different between the 2 groups of children.

\section{DISCUSSION}

In summary this study reveals a high prevalence of Hypotonia in 6-7 year old children in KwaZulu Natal. Significantly higher proportions of Asian male children presented with this disorder. Instrumented vaginal delivery and low levels of physical activity were strongly associated with the occurrence of Hypotonia.

The prevalence of Hypotonia in this study similar to that in almost all published research reports on $\mathrm{BCH}$ must be viewed with caution. This is due to the fact that diagnosis of $\mathrm{BCH}$ is difficult (Parush et al 1998, Soorani-Lunsing et al 1993) and often by exclusion (Richer et al 2001, Prasad and Prasad 2003). The diagnosis of exclusion may not even occur by the time the child outgrows the problems associated with Hypotonia (Richer et al 2001).

As far as prevalence proportions are concerned our data echo Parush's statement that infantile hypotonia is a common pediatric problem in Israel (Parush et al 1998). Dua et al (2001) reported $11 \%$ of their study group of floppy infants in India, unclassified. Our prevalence rates are significantly higher than westernized countries for which statistics are available: $4(5 \%) \mathrm{BCH}$ children out of a sample 79 infants (0-12 years) over a period of 20 years in Iowa (Russell et al 1992)); in Texas, 2-10\% clumsy children (Shanks-Sellers, 1995); 5-6\% in the United States of America (Missiuna et al 1995); $6-7$ percent with a maximum of $8.5 \%$ in Britain (Roussounis et al 1987); in Australia, $5-19 \%$ of children presented with Developmental Coordination Disorder
(Piek and Coleman-Carmen 1995). As indicated previously, the accurate diagnosis of $\mathrm{BCH}$ is difficult and the above reported prevalence rates may be misleading.

Dua et al (1998) reported that $40 \%$ of their floppy infants were male, thereby supporting our finding of a preponderance of this condition in Asian male children. Shanks-Sellers (1995) reported a higher prevalence of $\mathrm{BCH}$ in males in Texas while Piek and Coleman-Carmen (1995) reported that $53 \%$ of the identified children with DCD were male. In contrast, Shuper et al (1987), reported a female to male ratio of $2: 1$ in their sample of children presenting with BCH.

Parush et al (1998) found it interesting that the scores of motor performance of their children presenting with $\mathrm{BCH}$ correlated with the age at which the children began to walk. These researchers further explain that the reduced gross motor performance of the $6-8$ year old children with $\mathrm{BCH}$ lies in a lack of experience in various physical activities. This is related to our finding that decreased physical activity is more strongly associated with hypotonic than normal children. In Potchefstroom, South Africa, Du Toit and Pienaar (2002) noted gender differences in gross motor skills of preschool children. Three year old females were significantly more skilled in hopping and balancing on the right leg compared to their male counterparts. On the other hand 5-6 year old males were significantly better at the standing long jump and throwing for distance, than their female counterparts. Prinsloo and Pienaar (2003) in a study of DCD in a rural farming community concluded that although the prevalence of DCD in this community was higher than that in other communities, it is not influenced by physical activity. They suggest nutrition as a factor. SooraniLunsing et al (1993) showed that hypotonia was related to behaviour problems such as fearfulness and clumsiness but not to problems of cognition.

The present study showed that a larger proportion of the hypotonic children were delivered by assisted vaginal delivery. Neither Parush et al 's (1998) normal control subjects nor matched hypotonic children had any problems with either prenatal or birth histories. Trifero et al (2003) reported that the majority $(71 \%)$ of the children presenting with floppiness at birth but diagnosed as Prader-Willi syndrome, were delivered by Caesarean section.

\section{CONCLUSION}

This study revealed an alarming proportion of children in KwaZulu Natal presenting with Hypotonia. Since the diagnosis of $\mathrm{BCH}$ is elusive, it cannot be said that for certain these children have $\mathrm{BCH}$, hence this study has referred to these children as presenting with Hypotonia. Further testing may reveal as the international literature shows that some of these children may actually be more accurately diagnosed with more comprehensive diagnostic testing. This study also revealed the predisposing factors of Hypotonia and prevalence ratios in specific categories of the population. This study has clinical significance both for training curricula and clinical practice especially because health promotion is emphasized in the current health agenda.

\section{REFERENCES}

Dua T, Das M, Kabra M, Bhatia M, Sarkar C, Arora S, Sharma MC, Kalra V 2001 Spectrum of floppy children in Indian scenario. Indian Pediatrics 38(17): 1236-1243

Du Toit D, Pienaar AE 2002 Gender differences in gross motor skills in 3-6 year-old children in Potchefstroom, South Africa. African Journal of Physical, Health Education Recreation and Dance 8(2): 346-358

Missiuna C and Pollock N 1995 Beyond the Norm. Need for Multiple Sources of Data in the Assessment of Children. Physical and Occupational Therapy in Paediatrics 15(4): 57-74.

Parush S, Yehezkehel I, Tenenbaum A, Tekuzener E, Bar-Efrat/Hirsch I, Jessel A, Ornoy A 1998 Developmental correlates of school age children with a history of benign congenital hypotonia. Developmental Medicine and child Neurology 48:448-452

Piek JP and Coleman-Carmen R 1995 Kinesthetic sensitivity and motor performance of children with developmental coordination disorder. J Dev Med Child Neurology 37(11): 976-84. 
Prasad AN and Prasad C 2003 The floppy infant: contribution of genetic and metabolic disorders. Brain and development 27: 457-476.

Prinsloo A, Pienaar AE 2003 Prevalence of developmental coordination disorder and influences of physical activity levels and body composition on the children of farm workers: Flag-study. African Journal of Physical, Health Education Recreation and Dance 9(1): 151-164

Richer LP,Shevell MI, Miller SP 2001 Diagnostic profileof neonatal hypotonia: an 11 year study. Pediatric Neurology 25: 32-7

Roussounis SH, Gaussen TH, Stratton P 1987 A 2-year follow-up study of children with motor coordination problems identified at school entry age. Child Care Health Development 13(6): 377-91

Russell JW, Afifi AK, Ross MA 1992 Predictive value of electromyography in diagnosis and prognosis of the hypotonic infant Journal of Child Neurology 7:387-391

Shanks-Sellers J 1995 Clumsiness: Review of causes, treatments and outlook. Physical and Occupational Therapy in Paediatrics 15(4): 39-55.

Shuper A, Weitz R,Varsano I, Mimouni M 1987 Benign Congenital hypotonia A clinical study in 43 children. European Journal of Pediatrics 146:360-362
Soorani- Lunsingh RJ, Hadders- Algra M, Olinga AA, Huisjes HJ, Touwen BCL 1993 Is a minor neurological dysfunction at 12 years related to behaviour and cognition? Developmental Medicine and Child Neurology $35: 321-30$

Statistics South Africa 2002 Central statistical Services, Government of South Africa Press, Pretoria.

Trifero G, Liveri C, Bosio L, Gargantini L, Corrias A, Pozzan G, Crino A 2003 Neonatal Hypotonia: don't forget the Prader Willi syndrome Acta Paediatrica 92:1085-1089

\section{SOUTH AFRICAN SOCIETY OF PHYSIOTHERAPY Website: www.physiosa.org.za}

PO Box 92125, Norwood 211 Tel: (011) 485-1467,
Fax: (011) 485-1613

\section{EDITOR:}

- C.J. Eales, PhD

University of the Witwatersrand

Assistant Editors:

- S.L. Amosun, PhD

University of Cape Town

- M. Faure, Mphil

University of Stellenbosch

- J. Jelsma, PhD

University of Cape Town

- J. Mothabeng, Mphys

University of Pretoria

- A.V. Stewart, PhD

University of the Witwatersrand

INTERNATIONAL MEMBERS:

- A. Akinpelu, PhD

University College Hospital

Ibadan, Nigeria

- T.H.A. Kolobe, PhD

University of Illinois, Chicago

- K. Shepard, PhD

Temple University, Philadelphia

- R Herbert, PhD

Sydney University, Australia

- C. Partridge, $\mathrm{PhD}$

University of Kent, Canterbury

\section{REVIEWERS 2006}

- Amosun, Dele

- Constantinou, Dimitri

- Crous, Lynette

- David, Helen

- Diener, Ina

- Eales, Celie

- Faure, Mary

- Fearnhead, Lynn

- Frantz,Jose

- Frieg, Annette

- Gilder, Narina

- Gurie, Prinola

- Jelsma, Jennifer

- Jordaan, Ronel

- Joughin, Helen

- Krause, Tiney

- Louw, Quinette

- Maart, Soraya

- Mbambo, Nonceba

- M'Kumbuzi, Vyvienne

- Mothabeng, Joyce

- Mpofu, Ratie

- Myezwa, Hellen

- Paulsen, Tom

- Potterton, Joanne

- Puckree, Lina

- Stewart, Aimee

- Van Aswegen, Heleen

- Van Rooijen, Tania
ARTICLES FOR THE SOUTH AFRICAN J OURNAL OF PHYSIOTHERAPY:

\author{
A II articles must \\ be submitted \\ in an electronic format \\ directly to the Editor: \\ Prof CJ Eales, \\ P.O. B ox $356 \mathrm{M}$ ossel \\ Bay 6500
}

Email: eales@icon.co.za 